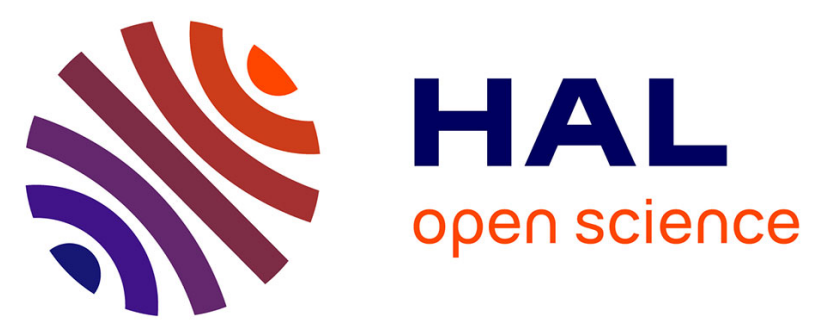

\title{
A Knowledge Base for Teaching Biology situated in the Context of Genetic Testing
}

\author{
Paul van Der Zande, Arend Jan Waarlo, Mieke Brekelmans, Sanne F
}

Akkerman, Jan D. Vermunt

\section{- To cite this version:}

Paul van Der Zande, Arend Jan Waarlo, Mieke Brekelmans, Sanne F Akkerman, Jan D. Vermunt. A Knowledge Base for Teaching Biology situated in the Context of Genetic Testing. International Journal of Science Education, 2010, pp.1. 10.1080/09500693.2010.525797 . hal-00653065

\section{HAL Id: hal-00653065 https://hal.science/hal-00653065}

Submitted on 17 Dec 2011

HAL is a multi-disciplinary open access archive for the deposit and dissemination of scientific research documents, whether they are published or not. The documents may come from teaching and research institutions in France or abroad, or from public or private research centers.
L'archive ouverte pluridisciplinaire HAL, est destinée au dépôt et à la diffusion de documents scientifiques de niveau recherche, publiés ou non, émanant des établissements d'enseignement et de recherche français ou étrangers, des laboratoires publics ou privés. 


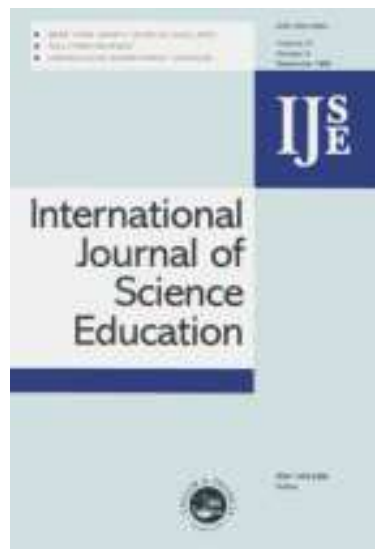

\section{A Knowledge Base for Teaching Biology situated in the Context of Genetic Testing}

\begin{tabular}{|r|l|}
\hline Journal: & International Journal of Science Education \\
\hline Manuscript ID: & TSED-2009-0374.R3 \\
\hline Manuscript Type: & Research Paper \\
\hline Keywords: & situated learning, content knowledge \\
\hline Keywords (user): & genetics education, moral education \\
\hline \multicolumn{2}{|l}{} \\
\hline
\end{tabular}

\section{SCHOLARONE ${ }^{m}$} Manuscripts 
A Knowledge Base for Teaching Biology situated in the Context of Genetic Testing

Abstract

Recent developments in the field of genomics will impact the daily practice of biology teachers who teach genetics in secondary education. This article reports on the first results of a research project aimed at enhancing biology teacher knowledge for teaching genetics in the context of genetic testing. The increasing body of scientific knowledge concerning genetic testing and the related consequences for decision-making indicate the societal relevance of such a situated learning approach. What content knowledge do biology teachers need for teaching genetics in the personal health context of genetic testing? This article describes the required content knowledge by exploring the educational practice and clinical genetic practices. Nine experienced teachers and 12 respondents representing the clinical genetic practices (clients, medical professionals, and medical ethicists) were interviewed about the biological concepts and ethical, legal, and social aspects (ELSA) of testing they considered relevant to empowering students as future health care clients. The ELSA suggested by the respondents were complemented by suggestions found in the literature on genetic counselling. The findings revealed that the required teacher knowledge consists of multiple layers that are embedded in specific genetic test situations: on the one hand, the knowledge of concepts represented by the curricular framework and some additional concepts (e.g. multifactorial and polygenic disorder) and, on the other hand, more knowledge of ELSA and generic characteristics of genetic test practice (uncertainty, complexity, probability, and morality). Suggestions regarding how to translate these characteristics, concepts, and ELSA into context-based genetics education are discussed. 
Introduction

In the last decennia, science teachers witnessed a shift of focus in science education. Dominant was a disciplinary approach where teaching the structure of science and disciplinary content were the main goals (Aikenhead, 2006; Roberts, 1988). However, not all students show affinity to academic science (Sadler, 2009), and the focus shifted to education relevant for the student's personal life and their preparation for future citizenship, i.e. science lessons that will help them to function in the complex 21st century (Aikenhead, 2006; Kolstø, 2001; Osborne, Collins, Ratcliffe, Millar, \& Duschl, 2003; Ryder, 2002). Roberts (1988) discerns a number of meta-perspectives on science teaching. Three of them are perspectives suitable within this focus on relevance for students: a) everyday coping, b) science, technology, and decisions emphasis, and c) self as explainer. Situated learning, or teaching science in context, provides a theoretical framework for supporting student preparation for their future role as citizens (Boersma et al., 2007; Gilbert, 2006; Ratcliffe \& Grace, 2003; Sadler, 2009). However, if science teachers adopt a situated learning approach, they need to be aware of the current state of the art in the authentic practice. This article aims to determine what secondary teachers need to know about the field of genetic testing to teach genetics and prepare students for situations in which they may become clients in genetic testing practice. Shulman (1986, 1987) distinguished seven categories of teacher knowledge. One of these categories is pedagogical content knowledge (PCK), which should enable experienced teachers to represent content in such a way that it takes into account the learning difficulties and student conceptions concerning that specific content knowledge. Another category is content knowledge, referring to knowledge about the content to be taught. From a situated learning perspective, it is important to determine the content knowledge of teachers not only by looking at current school subjects, but also by including recent insights from the authentic field, in this case the field of genetic testing. This study explores both the educational practice for the currently used content knowledge on genetic testing, as well as the authentic practice for the needed content knowledge. Before introducing our study, we elaborate in the following sections on situated learning, describe how genetics is currently addressed in 
secondary education, and briefly review some important developments in authentic genetic test practice.

\section{Situated Learning}

In his recent review, Sadler (2009) described how the idea that knowing and learning are situated in social practice gained renewed attention at the end of the last century. The situated learning approach connects to social-cultural theory by assuming that humans develop through participation in social cultural practices. Successful participation in practices requires local knowledge and the appropriate use of artefacts that can make learning meaningful for students. In such a social practice, people interact with each other and with materials and concepts (Greeno, 1998). Situated learning affects educational practice in at least two ways. First, in this approach the authentic practice becomes prescriptive and frames what is relevant to learn, thereby defining the concepts and knowledgeable skills in a meaningful way (Herrington \& Herrington, 2006; Lave \& Wenger, 1991). Second, in the situated learning approach students' learning takes place in relation to a situation that is deduced from the authentic practice. The fact that the authentic practice informs both the content to be taught and the situational framing of this content is based on the idea that the authentic context supports the specification of the concept's meaning and brings about the coherence of concepts within a larger whole (Herrington \& Herrington, 2006; Van Aalsvoort, 2004; Van Oers, 1998). Moreover, because students experience how the concepts can be applied in a recognisable situation, a situated learning approach aims to provide relevance to the learned content and promote student motivation (Boersma et al., 2007; Sadler, 2009). Given our interest in content knowledge, the question arises what knowledge can be derived from authentic practices as the basis for the required knowledge base of teachers concerned with situated learning. The required knowledge base needs to include concepts that are relevant to genetic testing practice as well as knowledge of the situational framing of these concepts. The latter means that teachers should be able to select and discuss genetic test situations in terms of how they represent the nature of 
decision-making processes in genetic testing practice. This is needed to guide students when they imagine themselves being clients ${ }^{1}$ in a prenatal or pre-symptomatic test situation as the basis for learning about genetics.

To determine the required knowledge base of teachers, it is necessary to acknowledge that 'the authentic practice' actually includes multiple social practices. The recent Dutch Biology Curriculum Innovation Programme distinguished three categories of authentic practice for secondary education: scientific practices, professional practices, and life-world practices (Boersma et al., 2007). This study aims to derive the required content knowledge of teachers by approaching people from each of these three practices about relevant concepts and decision-making in genetic test situations.

Situated Learning, Education for Citizenship, Socio-Scientific Issues, and Nature of Science The situated learning approach indicates how learning takes place, assuming that learning is an integral and inseparable aspect of social practice (Lave \& Wenger, 1991). The situated learning approach converges with teaching socio-scientific issues (SSI) and nature of science (NOS), two approaches that focus more on the why and what of teaching, stressing that education is meant to prepare for citizenship (Aikenhead, 2006; Osborne, Collins, Ratcliffe, Millar, \& Duschl, 2003; Ryder, 2001, 2002) Education for citizenship should lay the foundations for decisions and actions in adulthood in relation to society's controversial science-based problems (Ratcliffe \& Grace, 2003). In a school version of the authentic practice as suggested by Van Aalsvoort (2004), biology lessons can confront students with controversial issues where they have to learn to clarify their own position (Aikenhead, 2006; Levinson, 2006; Waarlo, 2003). Controversial issues that have conceptual as well as procedural connections to sciences, and are viewed as socially significant by the students, are labelled SSI (Sadler, 2004). Walker and Zeidler (2007) state that through teaching

${ }^{1}$ Most citizens involved with genetic testing are not ill (yet) and are not referred to as patients but as clients. In this article, the word client will be used. 
SSI, students can be empowered to not only reflect on the physical and social world around them but also on the (moral) principles behind science-based issues, the decisions made concerning them, and what those decisions mean in their view of a virtuous life. Authentic situations do not necessarily reflect SSI. For example, if we discuss animal nutrition in the context of keeping pets at home, this does not reflect a controversial issue or 'ill structured problem that are the hallmark of most SSI approaches' (Sadler, 2009, p. 19).

In a broader sense, when learning is situated in contexts such as the personal health context of genetic testing, it also relates to NOS. Although the latter is a complex and contested field (Alters, 1997; Helms \& Carlone, 1999; Lemke, 2001), Osborne et al. (2003) discern nine themes within the field of NOS. Some of these themes fit well in a situated learning approach to genetic testing. For example, the theme of science and certainty is concerned with the notion that much scientific knowledge is well established and beyond reasonable doubt, but that other scientific knowledge is not. Knowledge is the current 'state of the art' and is still in progress. For instance, the medical knowledge used in genetic testing is still developing and will change in the near future because of new evidence or new interpretations of old evidence. Another aspect of NOS mentioned by Osborne et al. (2003) that is even more appropriate in the health context of genetic testing does not belong to the abovementioned nine themes, namely moral and ethical dimensions in the development of scientific knowledge. Students who discuss possibilities within the genetic test practice should realise that some of those choices, although explained in scientific medical terms, are not value free and can conflict with their moral and ethical values. Although some authors suggest to include more aspects of NOS in teaching genetics in context, as will be discussed later, NOS defined in the way of Osborne et al. (2003) is focused on 'science in the making'. Within the life-world practice of genetic testing, the focus of the educational study reported here, i.e. the moral and uncertain implications of scientific knowledge for the personal lives of students, is of particular interest. Then, the focus is more on personal meaning in the student learning process, which is more in line with a socio-cultural perspective on teaching NOS (Helms \& Carlone, 1999; Lemke, 2001), that is 
students who give meaning to knowledge through internal and external dialogue about their own beliefs, values, and socio-cultural position towards genetic testing issues. In terms of NOS this can be seen as a mixture between distal and proximal knowledge of NOS. Distal knowledge of NOS can be operationalized as the understanding of NOS 'as students' explicit knowledge about the standards, practices, and products of the professional scientific community’ (Hogan, 2000, p. 53), and proximal knowledge is concerned with 'understanding students' notions about their own process of learning science' (op. cit., p. 54). This idea of personal meaning and decision-making relates again to the domain of SSI (Kolstø, 2006).

\section{Needs for Expanding the Curriculum on Genetic Testing}

Genetics in secondary education includes the knowledge of relevant curricular genetic concepts and heuristics such as Punnett squares and genealogical family trees. Recently, it has been argued that the biology curriculum should shift from focussing on single gene disorders to polygenetic disorders (Dougherty, 2009), and there is a growing awareness of the need to align the content of genetic teaching practice with the developments in the authentic practice (Boerwinkel, Verhoeff, \& Waarlo, 2008). The current focus on monogenetic heredity, common in classical Mendelian genetics, is thought to hinder the necessary insight into the crucial role of variation and individuality in modern genetics (McInerney, 2002), and does not prepare our students for effective participation as medical consumers (Dougherty, 2009). Other authors suggest the introduction of NOS aspects such as collecting and interpreting data or the uncertainty of scientific information (Ryder, 2001). Although the number of publications on teaching genetics in this controversial genetic test practice is substantial, the majority of the work focuses on higher education (Challen, Harris, Benjamin, \& Harris, 2006; Guttmacher, Porteous, \& McInerney, 2007; Hott et al., 2002; McInerney \& Collins, 2007; Plass, Baars, Beemer, \& Ten Kate, 2006). Moreover, most of these studies concentrated on the context of one or two diseases only, e.g. breast cancer, and most used Mendelian concepts such as gene, mutation, and family-related heredity chances (Richards, 
Hallowel, Green, Murton, \& Statham, 1995). For high school teachers, the relevant knowledge for teaching genetics in context is still to be explored. In doing so, we should keep in mind the advice of McInerney (1995):

'In genetics especially, the rate at which new knowledge is generated is so staggering that the pre-college curriculum often is overwhelmed by the accretion of isolated details and extensive vocabulary that do little to help students form a conceptual picture of genetics or of biology' (p. 786).

Curriculum documents can help determine the content that is addressed by teachers. We will focus on the formal and the operational curriculum according to Goodlad (1979). The former can be found in official national or institutional documents, whereas the latter deals with the way teachers implement the curriculum into their classrooms. For a description of the currently used content knowledge on genetic testing these two levels will be our reference points during the exploration of educational practice.

\section{The Authentic Practice of Genetic Testing}

Assuming that authentic practices can inform teaching practice and that not only the described educational shift in focus challenges science teachers, scientific developments also concerning the authentic practice itself are a major challenge for science teachers since they have to keep their disciplinary content knowledge up to date and position themselves towards new technological applications. This study elaborates on teaching biology in the personal health context of genetic testing. Recently, there has been a rapidly increasing body of knowledge in the field of genomics with important consequences for citizens. Scientists have sequenced the human genome and identified a number of genes relevant for identifying heritable diseases. This knowledge has a huge impact on biological and biomedical science, for instance by tackling health problems such as cancer by developing new targeted therapies, personalised medicine (Strausberg, Gimpson, Old, \& Riggins, 2004), and gene-based pre-symptomatic prediction of illness (Collins, Green, Guttmacher, 
\& Guyer, 2003). The practice of genetic testing also makes things complex because genetic testing is a complex process itself. Mostly, genetic testing is a so-called 'fact-and-value' issue, and these issues require an analysis that reflects different disciplines and perspectives (Yesley, 2008). Test situations differ from other medical situations because of the independency of the actual medical status, for instance one does not have to be ill at the time for a test to be useful. Moreover, the permanency of the genetic traits, implications for relatives, and problems clients possibly face with identity adds to the complexity (Nyrhinen, Leino-Kilpi, \& Hietala, 2004). Consequently, clients are faced with an increasing number of decisions, each with its own ethical, legal, and social implications. More and more, society expects its citizens to be capable of making reasonable decisions on these kinds of controversial issues. Therefore, one must be able to weigh scientific and biotechnological information together with ethical or legal considerations (Gearon, 2003) in a complex social setting (Veugelers \& Vedder, 2003). Thus, if teachers want to prepare their students for future decision-making, they do not only need an accurate knowledge of concepts but also a knowledge of the situational framing of these concepts, e.g. the ethical, legal and social aspects (ELSA) of genetic testing. In the literature, several systematic process descriptions of handling controversial issues, medical consultations in general, and the genetic testing process in particular can be found (e.g. Decruyenaere, 2003; Nyrhinen et al, 2004; Pin \& Gutteling, 2005; Resnik, 2003; Rowley, 2007; Van Neste, 1993; Wilfond, 1995). For instance, some research has been undertaken on public awareness and opinion about genomics (Pin \& Gutteling, 2005), on the ethical aspects (Nyrhinen et al, 2004), or the decision-making (Rowley, 2007). However, none of these descriptions are all inclusive or aimed at secondary education. Such a description is one of the sought-after outcomes of the study reported here. What can be derived from the literature is that the decision-making process within genetic testing, the authentic practice we were looking for, can be divided into the following four stages (Bolt et al, 2005; Decruyenaere, 2003; Grient Dreux, Kooijman, \& Korenromp, 2008; Nyrhinen et al, 2004).

Stage 1: Preparation phase, gathering information; 
Stage 2: Weighing information and decision-making 1;

Stage 3: The laboratory, analytical phase; and

Stage 4: The post-analytical phase - weighing information and decision-making 2, interpretation and processing the results (consequences), and support.

In this article, we will concentrate on knowledge concerning stages 1 and 2 because most problems emerge in these pre-analytical phases (Nyrhinen et al, 2004). As the results of the study will show, the first two stages are more relevant for education in this context. Furthermore, these problems are most informative to students not only because they are well aware they might think differently when they are adults and real clients, especially in stage 4 (Van der Zande, Brekelmans, Vermunt, \& Waarlo, 2009), but also because in stage 4 clients go through the same kinds of processes as in phase 1 and 2, only now they are focused on accepting test outcomes.

\section{Analytic Framework for Determining Required Content Knowledge}

This article aims to determine the required teacher content knowledge for teaching biology in the genetic testing context. What specific content knowledge is required on relevant concepts and the situational framing of these concepts in the processes of decision-making? The relevance of specific content knowledge for context-based education or teaching controversial socio-scientific issues has been stressed by several authors (Klop \& Severiens, 2007; Levinson, 2006; Levinson \& Turner, 2001; Sadler, 2009; Zeidler, Sadler, Simmons, \& Howes, 2005). However, a tailored description of the content knowledge used in authentic practices, e.g. in the health context of genetic testing, is to the best of our knowledge not available. If we accept the assumption stated above that in a social practice relevant knowledge is helpful or necessary for the successful participation in that practice, we have to explore this authentic practice to find out what this knowledge is. Consequently, if we want to find out what is new in this content knowledge compared with current content knowledge in secondary education, we have to compare this authentic practice-based knowledge claim with the 
current content knowledge already being taught by experienced biology teachers. Our research question can be formulated as follows:

What content knowledge do biology teachers need to teach genetics in the personal health context of genetic testing?

1. What is the content knowledge experienced teachers use when they teach genetics in the personal health context of genetic testing?

2. What is the content knowledge that can be derived from participants in the authentic practice of genetic testing?

Based on the earlier accounts of situated learning and the current developments in the field of genetic testing, required knowledge can be seen as related to different layers of the authentic practice as pictured in Figure 1. As stated above, within the situated learning approach learning takes place in relation to a situation; a specific client considering a specific test (grey-dotted box in Figure 1). This specific situation must be selected so that it represents the nature of the overarching medical practice of genetic testing (outer box in Figure 1). In the test situation, the concepts relevant for a proper understanding of genetic testing are under discussion (inner box Figure 1). Since the Human Genome Project, several researchers have suggested rethinking the biology curriculum, stating that it needs to also address the ELSA that are inherent to the decision-making processes in genetic testing practice (Baars et al., 2005; Boerwinkel, Verhoeff, \& Waarlo, 2008; Harvey et al., 2007; McInerney, 1995, 2002) (grey box in Figure 1). If teachers aim to empower students for their future role as health-care clients in genetic test situations, their required content knowledge must take account of these four layers of knowledge of the authentic practice. For the current biological content knowledge, used in today's biology classes, we explored educational practice by eliciting and describing the content knowledge of experienced teachers. Expertise is supposed to emerge only after long experience. Expert teachers have taught at least 10,000 contact hours (Ropo, 2004). In The Netherlands, that equals at least nine or 10 years of professional practice. 
In this study the knowledge and experiences of medical professionals and clients involved in genetic counselling were sought to inform us about the knowledge used in authentic clinical genetic practice. They could suggest what might be worthwhile for students to become prepared citizens, and this content knowledge can be compared with what is already taught in classrooms.

Insert Figure 1 about here

Method

\section{Participants}

For the exploration of the current state of domain knowledge in teaching expertise, nine experienced biology teachers were interviewed (Bt1-Bt9). This non-random typical case sample (Onwuegbuzie \& Leech, 2007) was selected from a list provided by biology teacher educators of the four biggest teacher education institutes in The Netherlands. These teacher educators were asked to provide us with names of teachers who were known for their expertise in teaching biology in context or were known for discussing SSI with their students. The actual selection was based on convenience (Ibid, 2007, p. 114); we received 15 names from the teacher educators and nine were available. The teachers were from eight different schools, with an average teaching experience of 20.7 years. Three out of the nine were female. Two worked at vocational schools, two in preuniversity classes, and five at schools with vocational and pre-university education. Five worked at schools with a religious denomination (three catholic, two protestant) and four worked at public schools.

To investigate the expertise that can be elicited from the clinical genetic practice, a stratified sample was used; 12 stakeholders were interviewed individually: four clients (C1-C4), four medical professionals (P1-P4: two physicians; one clinical geneticist, and one genetic counsellor), and four medical ethicists (Me1-Me4). The names of the medical ethicists and professionals were provided to us by the head of a science communication institute in the field of genomics. The ethicists 
represented four different academic medical centres. The medical professionals came from different cities and provided us with the names of their clients. Each of the three groups consisted of two females and two males. These three groups were not intended for comparative analysis, but to ensure data from different perspectives on genetic testing.

\section{Instrumentation}

Three instruments for data gathering were used. First, the teachers were interviewed in their own school buildings using a semi-structured face-to-face interview of 60 to 75 minutes. In the interviews, they were questioned about the content they taught in their genetic lessons. They were asked to compare the taught concepts with the formal Dutch curriculum. Concerning context-based knowledge of prenatal and pre-symptomatic genetic testing they were asked whether they had actually taught genetics in the context of genetic testing, what other concepts or knowledge became relevant in the classroom because of this context, and whether they discussed the ethical or other aspects of the test situation with their students in their lessons.

Second, the referents from the authentic genetic testing practice were interviewed using a semistructured face-to-face interview. The referents were interviewed for 60 minutes in their offices or homes (the clients). They were questioned about what clients must know or be able to do when they were supposed to participate successfully in a genetic testing situation, i.e. what biomedical concepts they considered relevant and what kind of knowledge they considered important within the process of genetic testing.

The interviews were recorded and imported as audio files into the software Atlas-ti (Murh, 2006). Third, because the ELSA mentioned in the interviews with the referents turned out to be exemplary rather than all inclusive, the ELSA suggested by the referents were complemented and ordered by suggestions found in the literature on the ELSA of genetic testing using the search engines Google Scholar and Omega with search criteria such as (prenatal) genetic testing, diagnostic genetic testing, moral aspects, ELSA, health-care, and care ethics in different combinations. 


\section{Data Analyses}

To answer the main research question, three analytic steps were undertaken. A first step entailed determining the current content knowledge of the experienced biology teachers. This was done by

(a) looking at the extent to which the teachers taught biology concepts according to the formal Dutch curriculum, (b) listing possible additional concepts relevant to genetic testing, and (c) determining their familiarity with ELSA. Second, the required content knowledge of teachers was determined by analysing the interviews of the 12 referents from the authentic practice on genetic testing. Finally, the ELSA suggested by the respondents were complemented by suggestions found in the literature on genetic counselling.

To show how those concepts mentioned by the referents fitted into a formal curriculum, the latest curriculum from the Dutch Biology Curriculum Innovation Board (CVBO) was considered the formal curriculum in this study (Boersma et al., 2007). The mentioned concepts were arranged into the concept matrix used by the CVBO to illustrate the coherence among biological concepts (Table 2). In this matrix, each concept was functionally placed within the organising framework of systems biology. Some concepts mentioned by the referents were related to human activities in the context of genetic testing, and were not yet part of the official CVBO concept matrix. These are presented separately as an added row to the matrix. The placing of new concepts into this matrix was discussed with two other researchers in biology education, one of them the chair of the CVBO, until consensus was reached. During the coding of the interviews we worked iteratively between the interview data and ELSA found in the literature. In the additional literature search, a saturation strategy was used. Reading stopped, after reading 35 books and articles, when the last two articles provided no single new moral consideration or dilemma and informational redundancy was reached (Onwuegbuzie \& Leech, 2007). These articles and books are listed separately in the references. For coding we used a grounded theory approach (Glaser \& Strauss, 1999). The suggestions from the referents and the literature were coded in an open way (Boeije, 2010), the interviews were 
fragmented, and the fragments were then compared among one other before being categorised and recategorised iteratively by the researcher with the findings from the literature and labelled with a code. This resulted, for instance, in the extensions of 'social' into 'psychosocial' in the ELSA codes. The inter-rater reliability of the three main codes (concepts, ELSA, and characteristics) were checked by another genomics researcher by comparison with the scoring of 18 interview fragments within these three categories: $n=$ number of categories (Cicchetti, 1976) and $2 n^{2}=18$ (Cohen's kappa $=0.87)$. Some of these fragments were rather lengthy, when the referents started e.g. with discussing a characteristic of the genetic test practice, then illustrated it with an ELSA, and using different biomedical concepts in both parts of the fragment. More than one code could be linked to these fragments. Within the main code 'characteristics', the four codes (uncertainty, probability, complexity, and morality) were checked for inter-rater reliability by comparing the scoring of $2 \mathrm{n}^{2}=$ 32 interview fragments within these four subcategories (Cohen's kappa $=0.74$ ). Finally, the Cohen's kappa of the three ELSA codes was determined (0.71). To illustrate the coding categories

used in the analyses some examples are listed in Table 1 with the corresponding utterances from the Deleted: 2 referents. In the end, the findings were summarised in two of the four stages of the decision-making process mentioned above:

Stage 1: Preparation phase, gathering information; and

Stage 2: Weighing information and decision-making 1 Insert Table 1 about here

Deleted: Insert Table 2 about herell Results

\section{Educational Practice}

Answering our research question about the content knowledge they used when teaching genetics in the personal health context, all experienced biology teachers reported that they taught the concepts mentioned in the Dutch examination syllabus (Table 2).

Deleted: 3 
'I used to concentrate on the classical heredity questions with Punnett squares etc. (Bold added by authors). And of course they had to understand everything about DNA duplication, and I used a strategy of travelling through the different organisation levels, extended with a practical, a cut, paste and paint assignment where they really had to make a model of DNA transcription. But now, although I still incorporate these issues, I'm engaged in a CVBO-like context around a cystic fibrosis patient, so I focus also on the symptoms of this disease and they have to use a concept from cytology like membranes etc.' (Bt1).

With the national curriculum in mind, we try to link the classic genetics with concepts like dominant, recessive, homozygote, and heterozygote to DNA, but unfortunately our method treats them separately' (Bt2; see also Quotation 1 in Table 1).

Only one teacher mentioned the importance of an additional concept not included in the formal

curriculum: 'epigenetic factors' (cf. Q3 in Table 1). The fact that the teachers taught in accordance with the formal curriculum was explained by their major concern to have their students pass the exams. One of the teachers (Bt2) even mentioned the national curriculum seven times as a reference point during the interview.

Some ELSA of genetic testing were distinguished by the teachers. Because they had also gained life experience, they all were familiar with some ELSA of genetic testing. These experienced teachers were able to recognise these aspects when they were confronted with them during their lessons. 'In discussing positive test outcomes ... I use the film "It's in the genes" of the Dutch Alliance of Genetic Interests Groups. At the end, one of the three brothers who were tested appears not to have the genetic predisposition for thyroid cancer, and I always hold the film for a moment there to point out to them that this boy feels emotionally disconnected from the rest of the affected family members' (Bt1).

These feelings were labelled in the literature as feelings of isolation and guilt (e.g. Decruyenaere, 2003; Wilfond, 1995). However, the interviews revealed that the familiarity with ELSA differed from teacher to teacher, and most teachers (seven out of nine) explicitly mentioned the importance 
of becoming more aware of different ELSA for their future teaching because they considered them an inherent part of the context-based content.

\section{The Authentic Practice of Genetic Testing}

First, from the assumption that clients were familiar with the medical framework of their test situation, they mentioned a number of biomedical concepts teachers should know to teach contextbased genetics. Next, some ELSA of genetic testing were labelled important and, consequently, should be part of the required teacher knowledge. However, the majority of the referents indicated that for preparing students for genetic testing teachers should be aware of the four characteristics of genetic practice: the uncertainty (nine out of 12 referents), probability (10 out of 12$)$, complexity (10 out of 12), and morality (12 out of 12) of testing (outer box of Figure 1). However, to understand these characteristics and accept the consequences of, say, the complexity of genetics for your life, a knowledge of biological concepts seemed to be necessary (inner box of Figure 1). To illustrate how all these concepts, ELSA and characteristics are interwoven in real life, this section ends with the story of Anne, one of the client-referents. Her story is an illustrative case study, based on a dense composition of quotations from her interview. Anne is a mother of two sons, one with a muscle disability, who looks back on her acquaintance with the world of genetic testing during the pregnancy of her third child (Box 1). We will discuss how the findings are reflected in this story.

\section{Medical Framework}

The referents in the authentic practice made it clear from the beginning that when clients have to decide on a genetic test, they first have to know what kind of heritable diseases they are looking for

(including causes, symptoms, life expectations, possible treatments (cf. Q6 in Table 1), and side -

effects), and which tests are available (pre-implementation, prenatal, pre-symptomatic). This medical information is inherent to genetic test practice (grey-dotted box in Figure 1). However, to understand this medical information clients must also have additional knowledge. The interviews 
with the participants in clinical genetic practices resulted in three sets of data, all informing the context-based knowledge base for teaching in this authentic practice.

\section{Biological Concepts}

The referents underlined the importance of sound conceptual knowledge. First, most concepts

mentioned in standard curricula were relevant in their eyes (Q2, Table 1). Some clients indicated 10

that not understanding these concepts was a problem for them.

'I did not know enough about genetics, and I do not understand probability at all. What I wanted to know and understand was how those tests worked and what they were looking for.

I do not understand how this disorder is linked to genes or something, and although I am highly educated, I have no affinity with genetics and probability' (C1).

The professional referents also mentioned extracurricular concepts (Q4, Table 1):

'Ok, you have Mendel, the high risk genes, and concepts like dominant or X-

chromosomal, but they also need to understand the low-risk genes, the polygenetic setting

where gene $\mathrm{a}+$ gene $\mathrm{b}+$ gene $\mathrm{c}+$ environment can also lead to a disorder' (P1).

'I think that everybody has to understand that, when one nucleotide in your DNA changes,

that does not always indicate that you will become ill, but that it adds a little to the risk you are running. And that such a change only leads to trouble when for instance you also get a virus infection. Students have to understand the genome variation and must be able to accept the complexity, the uncertainty, and the relative certainty' (P4).

New concepts mentioned by the referents of the authentic practice that were not yet part of the

CVBO concept matrix were added in bold in the matrix (Table 2). This approach of teaching increase the total number of concepts being taught. 


\section{ELSA}

Part of the teacher content knowledge of this medical health context are the ELSA of genetic testing. According to the referents of the authentic practice, these ELSA were not student content per se but should be part of a teacher's knowledge to recognise emerging ELSA during class discussions and provide them with language to clarify unclear student remarks, emotions, or intuitions. In the four stages of medical decision-making concerning genetic testing, the following aspects mentioned by the referents can be taken into account.

Stage 1: Preparation phase, gathering information. The first decision a client makes is whether she wants to have a test. There are different arguments for wanting to know or not wanting to know the test outcome:

- Ethical: religious arguments or arguments of responsibility and care, e.g. can you avoid harm and sorrow? (Q7, Table 1);

- Legal: is it legal; is the 'right not to know' applicable? (Wilfond, 1995); and

- Psychosocial aspects (Q8, Q9, Q12, Q13, Table 1, and Box 1): reassurance, feelings of (un)certainty, relief, guilt, isolation, anticipating decision regret, (in)dependency, responsibility, taboo, discrimination, stigmatisation, complexity, and timing (e.g. Nyrhinen, Hietala, Puukka, \& Leino-Kilpi, 2007).

After clients have decided that they want to know their genetic predisposition or that of their baby, the process of gathering information starts, and a lot of questions and knowledge can be relevant.

- Ethical: mostly the four principles of biomedical ethics are at stake - patient autonomy, beneficence, non-maleficence, and justice - completed with the principles of informed consent, privacy, care, and solidarity. Is there a conflict of interest? Which values are important for the client and what do they mean for her?

- Legal: what are the consequences for work, loans, and insurance? 
- Psychosocial: who is involved? (Q10, Q11, Table 1) What about the carrying capacity of the family (Box 1)? Can the client cope (emotionally) with a change of perspective, as is illustrated by the following quote from an expectant mother?

'The most striking aspect of the decision-making process was that I did not know Sophia. I had to make decisions on behalf of a person whose identity was undeclared, unknown, and unknowable' (Rosner, 2004, p. 20).

Stage 2: Weighing information and decision-making 1. After gathering information, stage 2 starts with the weighing process. Before deciding to undergo a test, the client has to examine, for instance, whether they understand the complex information, what it means to them, and whether they and their social environment can deal with it emotionally (Box 1). How are the values at stake balanced? Are the identified interests met and is help needed or not. After communicating the test outcome (stage 3, the laboratory, analytical phase), either positive or negative, a client must formulate a personal meaning (stage 4, interpretation and processing the results, consequences). Sometimes the difficult question of abortion is acute in a very short timeframe (Box 1), but in all cases emotions are involved and follow-up questions of responsibility and social consequences arise. Who else should be notified (Q10, Q11, Table 1): children, other family members, parents, or siblings? And finally, some questions are still unanswered: when, how serious, and how fast will the disease develop? Most problems can be found in stage 1, and concern the issue of informed consent. If students assume the position of a client, the question is whether or not they can understand everything. Can they assess the pros and cons, the risks, their own ethical position, and the medico-legal, emotional, and psychosocial consequences (Nyrhinen et al, 2004)?

\section{Characteristics}

Four characteristics relevant to the authentic genetic practice came to the fore, presented here by exemplary quotations. 
Uncertainty. Entering the consulting room of a doctor or genetic counsellor, people often expect to find straightforward answers and clear cut solutions. However, one cannot shape life according to one's own desires and directions (Box 1).

'Most people have inadequate knowledge of what is possible nowadays. They have unrealistic expectations and do not understand the nature/nurture aspects' (Me1). Moderation of these high expectations by future clients is one of the educational goals mentioned by the referents $(\mathrm{Q} 15$, Table 1). To understand the uncertainty of genetics, concepts such as important.

Probability. The referents agreed on the importance of a proper understanding of probability.

'Risks are evaluated situationally. Risks of close events, e.g. of getting ill, are overestimated, and more far away risks, e.g. risks you run in traffic, are underestimated. Even the language to present risks to people influences their perception' (Me1).

Not only did the professionals stress this point. The clients also mentioned that this was one of the most difficult aspects for them to grasp, and as a consequence, knowing the chance did not help at all (Box 1). Concepts such as 'chance' and 'risk assessment' help understand genetic probability.

Complexity. The referents stressed the importance of understanding the complexity of heredity.

'In the beginning most clients don't see the difference between confirmation and excluding possibilities. Confirmation is sometimes possible, ruling out mostly not' (P1).

'It is not a one-to-one relation between gene and disease. Students must understand the complexity of the numerous genes involved in a disease' (P2).

Often things are even more complex, and then clients do not go through these stages in an orderly way, and report other characteristics that influence their decision. 
- The process is cyclic; clients go through some of the stages more than once. It is possible that, after learning some of the consequences, you no longer want to have a test, although you started out wanting it (Q10, Table 1); emotions (Q20, Table 1); arguments the referents had for teaching genetics in this context (Box 1, Q8, Table 1);

- Choices are not only difficult, sometimes they have to be made in a chaotic and detached context. In this perspective, referents said that it is important that students learn how to personally reflect, even more than learning genetics and ethics (Q17, Q18, Table 1). What does it mean to be that ill? For your child or for you?; and

- According to the referents, emotional and rational considerations are important in education.

One client confirmed the importance of these considerations by going even one step further by stating that rational considerations didn't help at all (Q19, Table 1).

To understand the complexity of genetics, concepts such as 'multifactorial disorder', 'polygenic disorder', and 'genetic polymorphism' are also important.

Morality. According to the professionals, to be capable of making responsible decisions concerning genetic testing, one should also know something about ethics.

'Also certain values, principles, and moral experiences are relevant for this kind of considerations; respect for autonomy, the principle of human dignity, prima facie duties like non-injury. If you only reflect on intuitions or your own experiences, the narratives, it will not be enough' (Me2).

Knowledge alone is not enough; what does this information mean? (Q17, Q18, Table 1). The referents suggested that it could be informative to students to step out of the personal context and take a societal perspective. Then, a number of overarching issues can be raised including 
desirability, respectability, and the protection of the weak and those without voice (Q22, Q23, Table 1).

Or, what ethicist label 'expressive aspect' of an argument, and was voiced by Albert (2003): 'If society condones searching out and eliminating people like me, what does this say about how I am valued by others and how I should value myself?' (Albert in Levinson \& Reiss, 2003, p. 115).

And finally, are there (no) limits in what we can do or want to manipulate? Is this a personal responsibility or do we have enough societal guidance and legal regulations? In other words, do our ethics meet our medical and technical possibilities? According to the referents, these are important issues to address in education.

\section{The Story of Anne}

When teachers want to situate student learning in authentic practices such as genetic testing, they must be able to fathom the complex cases so typical of these practices. The experience of Anne, one of our client-referents, is an example of such a case and illustrates several of our findings. First, it is the specific authentic practice that prescribes the content knowledge and shapes the ELSA relevant for successful participation in the authentic practice: opting for a test with its possible far-reaching consequences. Anne's lack of biomedical knowledge, e.g. the biomedical background of the triple test, and her struggle with the concept of chance illustrates the first. The latter is shown by her emotional confusion, how she anticipated her decision regret, the role of others, her own background, and how she surveyed her carrying capacity. Next, her story illustrates the four common characteristics inherent to genetic testing practice, i.e. the difficulty she had with probability and the uncertainty of the situation. In fact, her story reflects one big ethical struggle, what to do in this complex situation, and why? Looking back on it now, she can voice it, but she would have been helped at the time had her biology teacher discussed this perspective with her. 
1

Insert Box 1 about here

\section{Conclusion and Discussion}

What content knowledge do biology teachers need to teach genetics in the personal health context of genetic testing? Current educational practice shed some light on the content knowledge we were looking for. This encompassed sound conceptual knowledge, included in the formal curriculum and necessary to help students pass their exams; concepts such as dominant, recessive, homozygote, heterozygote, DNA duplication, and transcription. The referents of the authentic practice brought up several other biological concepts, such as high risk genes, low risk genes, multifactorial disorders, and polygenic disorders (Table 2). According to them, these concepts are necessary for understanding the characteristics of uncertainty, complexity, probability, and morality. These characteristics were considered relevant for successful decision-making in genetic testing. Finally, the authentic practice, complemented by the relevant literature, provided an overview of the ELSA of genetic testing, which can be presented to teachers in four stages. These ELSA included ethical issues of informed consent and solidarity, dilemmas such as that between patient autonomy and guilt, legal issues concerning insurance, and social implications for relatives or future children (Table 1). Some of these ELSA were familiar to the expert teachers, but that differed depending on a teacher's life experience. Most thought it relevant to become more aware of these ELSA for their future teaching.

To the best of our knowledge this is the first time the authentic practice of genetic testing has been explored for the possible content knowledge of context-based biology teaching.

We started from the basic assumption of situated learning that the authentic practice is prescriptive and frames what is relevant to learn (Lave \& Wenger, 1991). The literature (e.g. Boersma et al., 2007; Nyrhinen, Leino-Kilpi, \& Hietala, 2004) gave us reason to believe that 
information about relevant knowledge and ELSA could be provided by the referents of the authentic practice. The results of this study confirmed this expectation.

This study, as some extracurricular developments, aim to introduce more contemporary concepts and genomics research techniques in school biology (Dougherty, 2009; Mil, Boerwinkel, Buizer-Voskamp, Speksnijder, \& Waarlo, 2010). However, most of the concepts mentioned do not form a part of the formal curriculum, and also exceed some earlier recommendations that were limited to the more classical Mendelian concepts (Richards et al., 1995). This might be an important side effect. If each context that will be explored to facilitate authentic learning results in extracurricular concepts, the issue of an overloaded biology curriculum must be addressed..

The recommendation of the referents to include the specific ELSA of genetic testing in biology education and their descriptions is helpful for describing the knowledge base for teachers who want to prepare students for the complexity of the testing situation. These ELSA could also help the debate on education for citizenship concerning this social practice (e.g. Aikenhead, 2006; Levinson \& Turner, 2001; Ratcliffe \& Grace, 2003).

The referents put an unforeseen emphasis on the characteristics of uncertainty, complexity, probability, and morality. This idea can be informative for biology teachers who want to apply the authentic learning approach because these characteristics are best understood via extracurricular concepts. For understanding uncertainty in genetics, for instance, the concepts of 'genomic variation', 'high and low risk genes', and 'single nucleotide polymorphisms' are needed. Moreover, concepts such as 'chance' and 'risk assessment' help explain genetic probability. The emphasis on the characteristics of morality and complexity underlined the fact that genetic testing is a socioscientific issue. Clients in a genetic test situation are confronted with a controversial and ill structured problem (Levinson, 2006; Sadler, 2009). Test outcomes are not always as unambiguous as they want them to be, and clients have to weigh scientific and medical information with complex social and ethical consequences, while rational considerations fall together with emotional confusion. 
The emphasis on the characteristic of uncertainty joins in with the discussion about the NOS and affirms its place in science education (Cobern, 2000; Lederman, 1999; Meichtry, 1999; Osborne, Collins, Ratcliffe, Millar, \& Duschl, 2003; Ryder, 2001). Ryder (2001) states that the knowledge of the role of uncertainty in science is one of the main areas of relevant science knowledge for functional scientific literacy. Next, insight in the making of science can also influence students' own learning of science (e.g. Hogan, 2000). The author's description of the possible interaction between the distal and proximal knowledge of NOS is of interest within our focus on student learning. According to Hogan, it could be that stimulated reflection in the two areas recursively supports the development of both. The distal knowledge of NOS, or the 'knowledge about the enterprise of professional science, including the epistemological commitments that undergird the formation and judgment of scientists' knowledge claims' (Hogan, 2000, p. 62), could influence the proximal knowledge of NOS, or the "metacognitive knowledge about and perspectives on personal experiences in scientific sense-making (i.e., learning), and personal epistemological commitments about scientific knowledge and knowing, especially in school contexts' (Ibid, 2000, p. 62), and vice versa.

This study focused on what teachers should know to prepare their students for the making of personal meaning of scientific knowledge rather than on broader socio-cultural aspects. We did not discuss aspects such as the economic, sociological, and political role of science in our modern world, the sociology of science, or the way science is practised and constructed by society (Brickhouse, 2001; Cunningham \& Helms, 1998; Lemke, 2001). In our view, these perspectives should be discussed with the teachers who want to develop the knowledge basis described here, because personal meaning making is not simply a matter of accepting facts and logical relationships. It helps to develop an identity by reflecting on one's system of beliefs and values, and is also based on the understanding that science is a part of larger communities and their cultures (Lemke, 2001). 
The fact that some clients experienced no support from rational considerations is in line with the findings of earlier research. For instance, some research has indicated that scientific information was either not understood or found irrelevant in dilemmatic situations (Dawson, 2003; Haidt, 2001; Layton, Jenkins, Macgill, \& Davey, 1993). This makes teaching in context an even greater challenge, one that surpasses the content perspective of teaching. It raises the question how people reason in dilemmatic situations, and whether reflection on that reasoning during their educational years can improve it.

Not only are the concepts in the formal curriculum relevant for teaching in context but so are additional concepts. This shows the importance of updating school curricula according to changes in the field (Table 2). Since our results indicate that teaching based on authentic practices could lead to a rethinking of curricula, initiatives should be taken to update science curricula in light of recent techno-scientific developments, such as new knowledge and technologies in genomics, and their implications for citizens. The first steps on this road have already been made (e.g. Boerwinkel, Verhoeff, \& Waarlo, 2008; Dougherty, 2009).

For improving teacher knowledge, the four layers of knowledge of the authentic practice should be taken into account (Figure 1) in teacher education programmes and the training of biology teachers. (Student) teachers need to acquire knowledge of the ELSA and the four-stage-process of testing helps them in doing so. Next, they require more knowledge of how concepts and ELSA can be conceived in the context of specific genetic test situations. Finally, they require knowledge of the four basic characteristics of genetic practice that make it so challenging.

This article has described the content knowledge, part of the necessary knowledge for teaching genetics in context. This raises questions about the other categories of teacher knowledge, in particular the PCK of teaching genetics in this genetic testing practice. Having described the concept knowledge for teaching genetics in the context of genetic testing, the question arises how 
this knowledge can be taught (Shulman, 1987). What teaching and learning activities are appropriate? This is an important question for future research.

In particular, we raised the question how people reason in dilemmatic situations, and whether reflection on that reasoning during their educational years can improve it. Owing to the moral aspect of the dilemmatic genetic test situations this kind of reasoning can be referred to as moral reasoning (Haidt, 2001), and our question indicates that it can be useful to develop teaching and learning activities for moral reasoning in science education. Although some research has already been dedicated to this question (Van der Zande, Brekelmans, Vermunt, \& Waarlo, 2009), more research is needed before teachers at different levels in secondary education can be accommodated with satisfying learning activities for (reflection on) moral reasoning.

\section{References}

Respondents of the Educational Practice and the Clinical Genetic Practice

Teachers Bt1 to Bt9, clients $\mathrm{C} 1$ to $\mathrm{C} 4$, physicians (and genetic counsellors) P1 to P4, and medical ethicists Me1 to Me4.

\section{Literature}

Insert Box 2 about here

Aikenhead, G. S. (2006). Science Education for Everyday Life - Evidence Based Practice. New York and London: Teachers College Press - Columbia University.

Alters, B. G. (1997). Whose Nature of Science? Journal of Research in Science Teaching, 34(1), $39-55$.

Baars, M. J. H., Scherpbier, A. J. J. A., Schuwirth, L. W., Henneman, L., Beemer, F. A., Cobben, J. M., et al. (2005). Deficient knowledge of genetics relevant for daily practice among medical students nearing graduation. Genetics in Medicine, 7(5), 295-301.

Bates, B. (2003). Prenatal screening halves CF births. Ob. Gyn. News online, 38(24), 2. 
Beauchamp, T., \& Childress, J. (2001). Principles of biomedical ethics. Oxford, Oxford University Press.

Boeije, H. (2010). Analysis in Qualitative Research. Thousand Oaks: SAGE Publications Inc.

Boersma, K. T., Graft van, M., Harteveld, A., Hullu de, E., Knecht-van Eekelen de, A., Mazereeuw, M., et al. (2007). Leerlijn Biologie van 4 tot 18 jaar. Uitwerking van de concept contextbenadering tot doelstellingen voor het biologieonderwijs [A learning line for biology for 4 to 18 based on a concept-context approach]. Utrecht: CVBO.

Boerwinkel, D. J., Verhoeff, R., \& Waarlo, A. J. (2008, 4 \& 5 december). A framework for rethinking science curricula in the genomics-era. Paper presented at the International Workshop Rethinking Science Curriculum in the Genomics Era, Utrecht, the Netherlands.

Bolt, L. L. E., Verweij, M. F., \& Van Delden, J. J. M. (2005). Ethiek in de praktijk [Ethics in Practice]. Assen: van Gorcum bv.

Borkenhagen, A., Brähler, E., Wisch, S., Stöbel-Richter, Y., Strauss, B., \& Kentenich, H. (2007). Attitudes of German infertile couples towards preimplantation genetic diagnosis for different uses: a comparison to international studies. Human Reproduction, 22(7), 20512057.

Brickhouse, N. W. (2001). Embodying Science: A Feminist Perspective on Learning. Journal of Research in Science Teaching, 38(3), 282-295.

Challen, K., Harris, H., Benjamin, C. M., \& Harris, R. (2006). Genetics Teaching for NonGeneticist Health Care Professionals in the UK. Community Genetics, 9, 251-259.

Cherry, M. J., \& Cherry. (2003). Beyond a western bioethics: voices from the developing world. The American Journal of Bioethics, 3(1), 67-68.

Cicchetti, D. V. (1976). Assessing inter-rater reliability for rating scales: Resolving some basic issues. British Journal of Psychiatry, 129, 452-456.

Cobern, W. B. (2000). The Nature of Science and the Role of Knowledge and Belief. Science \& Education, 9, 219-246. 
Collins, F. S., Green, E. D., Guttmacher, A. D., \& Guyer, M. S. (2003). A vision for the future of genomics research. A blueprint for the genomics era. Nature, 422, 835-847.

Cunningham, C. M., \& Helms, J. V. (1998). Sociology of Science as a Means to a More Authentic, Inclusive Science Education. Journal of Research in Science Teaching, 35(5), 483-499.

Dawson, V. (2003). Effect of a Forensic DNA testing Module on Adolescents' Ethical Decision Making Abilities. Australian Science Teachers' Journal, 49(4), 12-17.

De Visser, M. (2007). Preconception care: a good beginning. (20 September 2007). The Hague, Health Council of the Netherlands.

De Wert, G. (1999). Met het oog op de toekomst. Voortplantingstechnologie, erfelijkheidsonderzoek en ethiek. [With the eye on the future, reproduction technology, heredity research and ethics]. Maastricht University, Maastricht.

Decruyenaere, M. (2003, 15 november 2003). Psychosociale aspecten van genetisch onderzoek [Socio-psychological Aspects of Genetic Testing]. Paper presented at the Conference: "familiaal borst- en ovariumcarcinoom", Leuven, België.

Dols-Caanen, B., Konings, G., Gómez Garcia, E., \& Schrander-Stumpel, C. (2008). Counseling bij verdenking op erfelijke borstkanker. [Counselling in case of suspicion of heritable breast cancer] Patent Care, 35(1), 18-22.

Dougherty, M. J. (2009). Closing the Gap: Inverting the Genetics Curriculum to Ensure an Informed Public. The American Journal of Human Genetics, 85(10), 6-12.

Finck, C., Meister, U., Stöbel-Richter, Y., Borkenhagen, A., \& Brähler, E. (2006). Ambivalent attitudes towards pre-implantation genetic diagnosis in Germany. European Journal of Obstetrics \& Gynecology and Reproductive Biology, 126(2006), 217-225.

Frets, P. G. (1990). The reproductive decision after genetic counseling. Erasmus University, Rotterdam

Gearon, L. (2003). Learning to Teach Citizenship in the Secondary School. London, New York: Routledge Falmer. 
Gilbert, J. K. (2006). On the Nature of "Context" in Chemical Education. International Journal of Science Education, 28(9), 957-976.

Glaser, B. G., \& Strauss, A. L. (1999). The Discovery of Grounded Theory, Strategies for Qualitative Research. New York: Aldine de Gruyter.

Goodlad, J. I. (1979). Curriculum Inquiry: The study of curriculum practice. New York: McGrawHill.

Greeno, J. G. (1998). The Situativity of Knowing, Learning, and Research. American Psycholigist, $53(1), 5-26$.

Grient Dreux, A. d., Kooijman, H., \& Korenromp, M. (2008). Prenataal onderzoek. Over keuzes en dilemma's [Prenatal diagnosis. About choices and dilemmas]. Houten: Het Spectrum.

Grob, R. (2006). Parenting in the genomic age: the 'cursed blessing' of the newborn screening. New Genetics and Society, 25(2), 159-170.

Guttmacher, A. E., Porteous, M. E., \& McInerney, J. D. (2007). Educating health-care professionals about genetics and genomics. Nature Reviews, Genetics, 8, 151-157.

Haidt, J. (2001). The emotional dog and its rational tail: A social intuitional approach to moral judgement. Psychological Review, 108, 814-834.

Harvey, E. k., Fogel, C. E., Peyrot, M., Christensen, K. D., Terry, C. F., \& McInerney, J. D. (2007). Providers' knowledge of genetics: A survey of 5915 individuals and families with genetic conditions. Genetics in Medicine, 9(5), 259-267.

Helms, J. V., \& Carlone, H. B. (1999). Science Education and the Commonplaces of Science. Science Education, 83(2), 233-245.

Herrington, A., \& Herrington, J. (2006). What is an Authentic Learning Environment? In A. Herrington \& J. Herrington (Eds.), Authentic Learning Environments in Higher Education. Hersley: Information Science Publishing. 
Hietala, M., Hakonen, A., Aro, A. R., Niemelä, P., Peltonen, L., \& Aula, P. (1995). Attitudes toward Genetic testing among the general population and relatives of patients with a severe genetic disease: a survey from Finland. American Journal of Human Genetics, 56, 1493-1500.

Hogan, K. (2000). Exploring a Process View of Students' Knowledge about the Nature of Science. Science Education, 84(1), 51-70.

Hott, A. M., Heuther, C. A., McInerney, J. D., Christianson, C., Fowler, R., Bender, H., et al. (2002). Genetics Content in Introductory Biology Courses for Non-Science Majors: Theory and Practice. BioScience, 52(11), 1024-1035.

Klop, T., \& Severiens, S. (2007). An Exploration of Attitudes towards Modern Biotechnology: A study among Dutch secondary school students. International Journal of Science Education, 29(5), 663-679.

Kolstø, S. D. (2001). Scientific Literacy for Citizenship: Tools for Dealing with the Science Dimension of Controversial Socioscientific Issues. Science Education, 85(3), 291-310.

Kolstø, S. D. (2006). Patterns in Students' Argumentation Confronted with a Rick-focused Socioscientific Issue. International Journal of Science Education, 28(14), 1689-1716.

Lave, J., \& Wenger, E. (Eds.). (1991). Situated Learning Legitimate Peripheral Participation (Vol. 302). Cambridge: Cambridge University Press.

Layton, D., Jenkins, E., Macgill, S., \& Davey, A. (1993). Inarticulate Science? Perspectives on the Public Understanding of Science and Some Implications for Science Education. East Yorkshire: Studies in Education Ltd.

Lederman, N. G. (1999). Teachers' Understanding of the Nature of Science and Classroom Practice: Factors That Facilitate or Impede the Relationship. Journal of research in science teaching, 36(8), 916-929.

Lemke, J. L. (2001). Articulating Communities: Sociocultural Perspectives on Science Education. Journal of Research in Science Teaching, 38(3), 296-316. 
Levinson, R. (2006). Towards a Theoretical Framework for Teaching Controversial Socio-scientific Issues. International Journal of Science Education, 28(10), 1201-1224.

Levinson, R., \& Reiss, M. (2003). Key Issues in Bioethics. London: RoutledgeFalmer.

Levinson, R., \& Turner, S. (2001). Valuable Lessons. Engaging with the social context of science in school: Institute of Education, University of London.

McInerney, J. D. (1995). The Human Genome Project and biology education. BioScience, 45(11), 786-791.

McInerney, J. D. (2002). Education in a Genomic World. Journal of Medicine and Philosophy, 27(3), 369-390.

McInerney, J. D., \& Collins, F. S. (2007). Core Competencies in Genetics for Health Professionals, Third Edition.: National Coalition for Health Professional Education in Genetics (NCHPEG).

Meichtry, Y. J. (1999). The Nature of Science and Scientific Knowledge: Implications for a preservice Elementary Methods Course. Science \& Education, 8, 273-286.

Mil, M. H. W., Boerwinkel, D. J., Buizer-Voskamp, J. E., Speksnijder, A., \& Waarlo, A. J. (2010). Genomics education in practice. Evaluation of a mobile lab design. Biochemistry and Molecular Biology Education, In press.

Murh, T. (2006). ATLAS.ti (Version 5.12.18). Berlin: ATLAS.ti Scientific Software Development $\mathrm{GmbH}$.

Nyrhinen, T., Hietala, M., Puukka, P., \& Leino-Kilpi, H. (2007). Consequences as ethical issues in diagnostic genetic testing - a comparison of the perceptions of patients/parents and personnel. New Genetics and Society, 26(1), 47-63.

Nyrhinen, T., Leino-Kilpi, H., \& Hietala, M. (2004). Ethical issues in the diagnostic genetic testing process. New Genetics and Society, 23(1), 15.

Onwuegbuzie, A. J., \& Leech, N. L. (2007). A Call for Qualitative Power Analyses. Quality \& Quantity, 41, 105-121. 
Osborne, J., Collins, S., Ratcliffe, M., Millar, R., \& Duschl, R. (2003). What “Ideas-aboutScience', Should Be Taught in School Science? A Delphi Study of the Expert Community. Journal of Research in Science Teaching, 40(7), 692-720.

Pin, R. R., \& Gutteling, J. M. (2005). Publieksonderzoek Genomics 2005 [General Public Research Genomics]. Enschede: Faculty of Social Science, Twente University.

Plass, A. M. C., Baars, M. J. H., Beemer, F. A., \& Ten Kate, L. P. (2006). Genetics Education for Non-Genetic Health Care Professionals in the Netherlands (2002). Community Genetics, 9, 246-250.

Ratcliffe, M., \& Grace, M. (2003). Science Education for Citizenship, Teaching Socio-Scientific Issues. Maidenhead-Philadelphia: Open University Press.

Resnik, D. B. (2003). Genetic testing and primary care: a new ethic for a new setting. New Genetics and Society, 22(3), 245-256.

Richards, M. P. M., Hallowel, N., Green, J. M., Murton, F., \& Statham, H. (1995). Counseling Families with Hereditary Breast and Ovarian Cancer: A Psychosocial Perspective. Journal of Genetic Counseling, 4(3), 219-233.

Roberts, D. A. (1988). What Counts as Science Education? In P. J. Fensham (Ed.), Development and Dilemmas in Science Education (pp. 27-54). London: Palmer Press.

Ropo, E. (2004). Teaching Expertise. Empirical findings on expert teachers and teacher development. In H. P. A. Boshuizen, R. Bromme \& H. Gruber (Eds.), Professional Learning: Gaps and Transitions on the Way from Novice to Expert (Vol. 2). Dordrecht, Boston, London.: Kluwer Academic Publishers.

Rosner, J. (2004). Lullabies for Sophia. Hasting Center Report, 34(6), 20-21.

Rowley, E. (2007). On doing 'being ordinary': women's account of BRCA testing and maternal responsibility. New Genetics and Society, 26(3), 10.

Rudnick, J. (Writer) (2007). In the family, how much do you sacrifice to survive? [DVD]. In J. Rudnick (Producer). USA: Ro*Co Films International, llc. 
Ryder, J. (2001). Identifying Science Understanding for Functional Scientific Literacy. Studies in Science Education, 36(1), 1-44.

Ryder, J. (2002). School science education for citizenship: strategies for teaching about the epistemology of science. Journal of Curriculum Studies, 34(6), 637-658.

Sadler, T. D. (2004). Informal Reasoning Regarding Socioscientific Issues: A Critical Review of Research. Journal of Research in Science Teaching, 41(5), 513-563.

Sadler, T. D. (2009). Situated learning in science education: socio-scientific issues as contexts for practice. Studies in Science Education, 45(1), 1-42.

Shulman, L. S. (1987). Knowledge and Teaching: Foundations of the New Reform. Harvard Educational Review, 57(1), 1-22.

Stratton, M. R., \& Rahman, N. (2008). The emerging landscape of breast cancer susceptibility. Nature Genetics, 40(1), 17-22.

Strausberg, R. L., Gimpson, A. J. G., Old, L. J., \& Riggins, G. G. (2004). Oncogenetics and the development of new cancer therapies. Nature, 429, 469-474.

Twomey, J. G. (2006). Issues in genetic testing of children. The American Journal of MaternalChild Nursing 31(3), 14.

Vähäkangas, K. (2001). Ethical implications of genetic analyses of individual susceptibility to diseases. Mutation Research, 482, 105-110.

Van Aalsvoort, J. (2004). Activity theory as a tool to address the problem of chemistry's lack of relevance in secondary school chemical education. International Journal of Science Education, 26(13), 1635-1651.

Van Baarsen, B. (2003). DNA diagnostiek bij kinderen met een neuromusculaire aandoening: geruststelling of onzekerheid [DNA diagnostic of neuromuscular disorder by children]. NMZbulletin, 14(23). 
Van der Zande, P. A. M., Brekelmans, M., Vermunt, J. D., \& Waarlo, A. J. (2009). Moral reasoning in genetics education. Journal of Biological Education 44(1), 31-36.

Van Kleffens, T., Van Baarsen, B., \& Van Leeuwen, E. (2004). The medical practice of patient autonomy and cancer treatment refusal: a patients' and physicians' perspective. Social Science \& Medicine, 58, 2325-2336.

Van Neste, F. (1993). Recht en ethiek ten aanzien van de geneeskunde [Justice and Ethics in Medical Science]. Ethische perspectieven, KU Leuven(1), 8-16.

Van Oers, B. (1998). From Context to Contextualizing. Learning and Instruction, 8(6), 473-488.

Veugelers, W., \& Vedder, P. (2003). Values in Teaching. Teachers and Teaching: theory and practice, $9(4), 377-389$.

Waarlo, A. J. (2003, August 19-23). Acquiring genomics-related opinion-forming competence Developmental research into a problem posing learning and teaching strategy. Paper presented at the ESERA, Noordwijkerhout, the Netherlands.

Walker, K. A., \& Zeidler, D. L. (2007). Promoting Discourse about Socioscientific Issues through Scaffolded Inquiry. International Journal of Science Education, 29(11), 1387-1410.

Wilfond, B. S. C. (1995). ASHG/ACMG Report: Points to Consider: Ethical, Legal, and Psychological Implications of Genetic Testing in Children and Adolescents. American Journal of Human Genetics, 57, 1233-1241.

Wüstner, K., \& Heinze, U. (2007). Attitudes towards preimplementation genetic diagnosis - a German and Japanese comparison. New Genetics and Society, 26(1), 1-27.

Yesley, M. S. (2008). What's ELSI got to do with it? Bioethics and the Human Genome Project. New Genetics and Society, 27(1), 1-6.

Zallen, D. T. (1997). Confronting science: the dilemma of genetic testing. Humanities, 18(2), 3437.

Zeidler, D. L., Sadler, T. D., Simmons, M. L., \& Howes, E. V. (2005). Beyond STS: A ResearchBased Framework for Socioscientific Issues Education. Science Education, 89(3), 357-377. 
The genetic test practice

Ethical, Legal \& Socio-psychological aspects

The genetic test situation

Concept 1 , concept $2 \ldots .$.

...... concept $\mathrm{n}-1$, concept $\mathrm{n}$.

Figure 1. Different layers involved in the genetic test practice. 
Table 1. Coding: Exemplary codes with the corresponding utterances from the referents.

\section{Examples of codes}

- Main Codes

Sub Codes level 1

- Sub codes, level 2

Sub codes, level 3

\section{- $\quad \mathbf{C}=$ Concepts}

$\mathrm{CC}=$ Concepts Curricula

$\mathrm{CNC}=$ Concepts None Curricular

- ELSA

$\mathrm{E}=$ Ethical

- $\quad \mathrm{E}-\mathrm{V}=$ Values \& moral principles

$\mathrm{E}-\mathrm{V}-\mathrm{A}=$ Autonomy

E-V-I $=$ Informed consent

$\mathrm{E}-\mathrm{V}-\mathrm{J}=$ Justice

$\mathrm{E}-\mathrm{V}-\mathrm{NM}=$ Non maleficence

E-V-P = Privacy

$\mathrm{E}-\mathrm{V}-\mathrm{Pr}=$ Protectability

$\mathrm{E}-\mathrm{V}-\mathrm{PV}=$ Prima facie values

$\circ \quad \mathrm{PW}=$ Protecting the weak

E-V-S = Solidarity

○ $\quad \mathrm{E}-\mathrm{D}=$ Dilemma

E-D-A/Q = Autonomy - Guilt

E-D-T/NT Treatment or not

E-D-B/NM care - avoiding harm

E-D-T: Time dilemma

$\mathrm{L}=$ Legal

○ $\quad \mathrm{L}-\mathrm{La}=\mathrm{Law}$

L-LA-NK = Right not to know

- L-Lo $=$ Loans

L-I = Insurances

$\mathrm{S}=$ Socio-psychological

- S-F = consequences for family

S-ADR $=$ Anticipating Decision Regret

- $\quad \mathbf{C h}=$ Characteristics

$\mathrm{Ch}-\mathrm{U}=$ Uncertainty

Ch-C $=$ Complexity

CH-P = Probability

$\mathrm{Ch}-\mathrm{M}=$ Morality

- $\quad \mathbf{O}=$ Other (Remaining codes)

$\circ \quad \mathrm{O}-\mathrm{D}=$ Disability rights

- O-EA = Expressive aspect
Exemplary utterances using 23 of the original 267 quotations.

\section{Concepts}

CC: Q1 \& Q2

II use a standard method ... where the Mendelian genetics is completely covered, with Punnett squares and family trees and all that ... and we link it to the molecular genetics in the higher classes ... they construct the double helix of DNA with paper symbols of the different bases and via all the different steps such as messenger RNA they build proteins "

'Some clients lack knowledge or understanding. They ask, for example, "what are those chromosomes?" or "DNA what is that, you can't even see it?" Often they can't believe that this "invisible" DNA determines so much"

CNC: Q3 \& Q4

I also discus cytoplasmatic factors, I start with epigenetic factors, it is fascinating to tell about ....'

...I think students have to understand the usual concepts such as dominant - recessive, but also the polygenetic setting .... and the whole genome screening, I think they will be confronted with it within 10 years and then they must understand high and low risk genes ... if they only understand the black or white Mendelian genetics, they cannot understand the complexity of most genetic diseases

\section{ELSA}

E-V-Pr: Q5

Concerning technical possibilities like genetic testing, you have to think about the criterion of desirability and the criterion of carefulness. We must reflect on the question whether it is desirable or not to have genetic testing at all. What does it tell us about illness and pregnancy? Are thes still natural processes? But you must not think that you can stop these developments. So, it is important to discuss the circumstances under which these tests may be done'

E-D-T/NT: Q6

'Imagine you find out that you have a genetic disorder, what can you do? If you cannot prevent or cure it at all, a very important consideration for a doctor is: "do I want to expose my patient to a medical examination when it will bring nothing, just the information that something terrible is bound to happen and you cannot do anything to prevent it?" For the patient the question is whether he or she wants to participate in a process when nothing can be done about it?

E-D-B/NM: Q7

'For most expectant mothers it's a big problem, dilemma, if she knows her baby has a genetic disorder. "May I bring this upon my child, what is my responsibility as future parent? Don't we have the responsibility to save them from this misery?" They have to balance this with the felt responsibility of care for their future child. The idea that many women end their pregnancy for trivial reasons is a fable; the vast majority of them experience this as an emotionally difficult dilemma

E-D-T: Q8

'Suppose you decide to abort your child, you can never undo that. You will live the rest of your life with the knowledge that you have aborted a child on genetic grounds. Suppose you do not abort it. Then you have a comparable situation; you have to live with the fact that a child is born child on genetic grounds. Suppose you do not abort it. Then you have a comparable situation; you have to live with the fact that a child is born
that will probably require help and care the rest of its life. After a test, in a timeframe of two weeks you'll have to decide something that impacts that will probably require help and care the rest of its life. After a test, in a timeframe of two weeks you'll have to decide something that impacts
the rest of your life. I think that is far too radical. I think that in your adolescence, you have to be trained to deal with this kind of dilemmas. These vital questions cannot be postponed to the moment you are confronted with them'

E-D-A/Q: Q9

'With the introduction of patient autonomy they also became responsible for their decisions, although they cannot know all the consequences.. imagine they choose a certain treatment and they become even more sick, than it they are also guilty themselves, so autonomy, becomes responsibility and can become guilt

S-F: Q10 \& Q11

'When I finally realised that before they could allow me to do a test, they wanted to involve my brother in the process, I didn't persist, I could not bother him with my problems'

'Sometimes, when a client realises that involvement of family members is necessary, they shy away, e.g. because they don't know these distant relatives or think that they can't burden them with these problems'

S-ADR: Q12 \& Q13

'.. it is the phenomenon that people probably accept e.g. a prenatal test more easy to avoid that they have to say in the future... if we only ...' 'Research indicates that people accept prenatal diagnosis because of what we call anticipating decision regret. They don't want to run the risk of blaming themselves afterwards for not having done everything that's possible to avoid the future misery of their children'
Source

referent

$\mathrm{T} 1$ 


\section{Characteristics
$\mathrm{CH}-\mathrm{C} / \mathrm{U}: \mathrm{Q} 14$}

I think that everybody has to understand that, when one nucleotide in your DNA changes, that does not always indicate that you will become ill, but that it adds a little to the risk you are running. And that such a change only leads to trouble when for instance you also get a virus infection.

Students have to understand the genome variation and must be able to accept the complexity, the uncertainty and the relative certainty"

'Students should be confronted with the limitations. They must be aware that you cannot explain everything with genetics. Biology lessons in a societal context should make them think about what you can do with knowledge, and what you want to do with knowledge. Personally, as well as socially. You can't always get what you want. What are the possibilities? We are bound to laws. We are bound to the possibility to trace a genetic predisposition. If it is a low risk gene and the medical test is expensive, then such a test will not be offered to the client. Some clients find this predisposition. If it is a low risk gene and the medical test is expensive, then such a test will not be offered to the client. Some clients find if
difficult to accept, they want everything written on paper. They end up by visiting websites where all kinds of tests are being offered. I think education can help people to become informed about what you can learn from these tests. What is certain, what can be proved for sure, and what education can help people to become infor
is information that won't help you at all?'

CH-P: Q16

CH-M: Q17 \& Q18

but for each human being it is 'yes' or 'no', and that's what they want to know'

'Although we have these four principles, e.g. autonomy and justice, I think it is very important to relativise that. It is also very important that we learn how to reflect on a situation in a personal way, that you realise that a situation is always much more complex than it seems at first glance, that you realise how you intuitively would like to act in a situation and that you are willing to reflect on this intuition, this preconceived opinion... it is important to teach our students that uncertainty is a great value, because this 'not knowing' gives you the opportunity and the time to grasp the complexity of these dilemma's'

'How to deal with all this information, how to deal with all the advice you get from the people around you, how to reflect on your first intuitive reactions, I think that is the most important goal of education'

CH-C: Q19, Q20 \& Q21

'Although my wife is working in the healthcare and I am a biologist, at the moment we were confronted with the fact that our child had Down syndrome, this knowledge had no use. At that moment we were confronted by different emotions and moral questions. Biomedical knowledge didn't help us at all'

I I felt all kinds of emotions, I was frightened. There was chaos in my head: what do I have to do now? I thought: "help, I know nothing about this". And all the people I esteem highly, gave me different advice, it was very confusing'

'They must understand the difference between disposition for a disease and getting a disease. Or the difference between having the disposition and being a carrier'

O-D/EA: Q22 \& Q23

'Are we going to protect the weak and the vulnerable? Whose responsibility is that, the client's, the doctor's or of society as a whole? And how is this responsibility related to the principle of the autonomous patient?'

'When you think about the status or respectability of a foetus, you have to deal with the disability rights criticism. Disabled people, or those closely related, find themselves discriminated by these kinds of questions' 
Table 2. List of biological concepts for genetics education in the health context of genetic testing, in the extended CVBO matrix (Boersma et al., 2007).

\begin{tabular}{|c|c|c|c|c|c|}
\hline \multirow{2}{*}{$\begin{array}{l}\text { Levels of biological } \\
\text { organisation }\end{array}$} & \multicolumn{5}{|c|}{ System concepts } \\
\hline & Biological unit & $\begin{array}{l}\text { Self regulation and } \\
\text { self organisation }\end{array}$ & Interaction & Reproduction & Evolution \\
\hline Molecular & $\begin{array}{l}\text { Adenine (A) } \\
\text { Allele } \\
\text { Amino acids } \\
\text { Base } \\
\text { Cytosine (C) } \\
\text { DNA } \\
\text { Gene } \\
\text { Guanine (G) } \\
\text { Nucleotide } \\
\text { Protein } \\
\text { RNA } \\
\text { Thymine (T) } \\
\text { Uracil (U) } \\
\end{array}$ & $\begin{array}{l}\text { Base pair } \\
\text { Base sequence } \\
\text { Double helix }\end{array}$ & $\begin{array}{l}\text { Dominant } \\
\text { High/low risk gene } \\
\text { Recessive } \\
\text { Single nucleotide } \\
\text { polymorphism (Snip) }\end{array}$ & & $\begin{array}{l}\text { Genetic polymorphism } \\
\text { Mutation }\end{array}$ \\
\hline Cellular & $\begin{array}{l}\text { Autosome } \\
\text { Chromosome } \\
\text { Genome } \\
\text { Sex chromosome } \\
\text { X chromosome } \\
\text { Y chromosome }\end{array}$ & $\begin{array}{l}\text { Genetic code } \\
\text { Mitosis } \\
\text { Cancer }\end{array}$ & & $\begin{array}{l}\text { Diploid } \\
\text { Haploid } \\
\text { Heterozygote } \\
\text { Homozygote } \\
\text { Meiosis }\end{array}$ & \\
\hline $\begin{array}{l}\text { Organ } \\
\text { system }\end{array}$ & & Cancer & & & \\
\hline Organism & & Cancer & $\begin{array}{l}\text { Multifactorial disorder } \\
\text { Polygenic disorder }\end{array}$ & & Chance \\
\hline Population & & & & $\begin{array}{l}\text { Mendelian inheritance } \\
\text { Pedigree }\end{array}$ & Genomic variation \\
\hline \multicolumn{6}{|l|}{ Ecosystem } \\
\hline \multicolumn{6}{|l|}{ Biosphere } \\
\hline $\begin{array}{l}\text { Context concepts } \\
\text { (Domain specific tec }\end{array}$ & and activities) & Sequ & ing, genetic testing, micro & array, whole genome sc & ning, risk assessment \\
\hline
\end{tabular}


Box 1. Concepts, ELSA, and characteristics of the genetic test practice illustrated by a client story.

\section{The story of Anne}

Looking back on it now, I realize that I did those tests, the Triple test, without proper considerations in advance. All I really wanted was reassurance. And of course that is a strange starting point, because there is a chance that you won't be reassured. I think that most people doing punctures and other such tests expect to be reassured and ready to enjoy their pregnancy afterwards. For me this was a naïve way to view such a test. Especially a test that will only give you a chance, a percentage. Because then in fact you still know nothing. I would never do that test again. If I ever was to feel the need for such a test I would do a puncture or some other test that would give me more certainty. And I would have thought about what I would do with the possible results in advance, so I would be able to anticipate on them. After John, who could not even walk though he was three, my mistake was that I thought I could not handle another child with a handicap. I thought I could not endure another infant who could not do anything on his own. So I decided to get myself some reassurance. And although the echo looked ok, I was worried, so I did a test that was not risky for the baby. You are so relieved that something can be done, so you do it, because you don't want to feel like you didn't do everything possible for your child. When my husband got the phone call and the doctor told him that I had a risk of one out of $\mathbf{2 8 0}$ or something, my husbanded responded with: "well that sounds good". But it was not good at all! It was an increased risk, and I should visit the doctor. He told me that my risk was four times higher than normal, and suddenly it sounded completely different. One out of 280 or four times higher than normal. But in the mean time I was pregnant for 13 or 14 weeks. The triple test indicated it wise to puncture my placenta. That tests' outcome could be expected within one or two weeks and then I had exactly one week left to decide whether I wanted an abortion or not. How could I decide in two weeks time over the life or death of my child? I was just in time and could "still do something about it" as the doctor put it. But my body already showed my pregnancy, and I felt life inside me, little movements. So I looked down at my belly and thought; doing something about it? No way, it's my baby. I felt so unhappy, I didn't want that puncture, in fact I only wanted to tuck it all away. If they had told me I had a chance of 50 percent, maybe. But even then I didn't want to make that kind of decision, I didn't want to decide for an abortion, because I was afraid I would regret it in the end. On the other hand, I know it could mean a lot of special care. And I am not religious in the way that I believed this to be the burden I had to carry. I did not think I could manage it without depriving my other two kids, my family. The doctor strongly advised me to do the puncture and was looking very worrisome. So I came home crying and told my husband I had a chance of one out of 280. And he responded: 'what kind of a chance is that anyhow? If you step out the front door, you might have the same chance to get hit by a car.' Later we saw on the internet that a puncture had the same chance of miscarriage, so what kind of choice was this? I was so confused, so unprepared. When you have a healthy child with Down syndrome, it can still live a happy life. However, if it has to undergo all kinds of operations, and it would suffer a lot, what kind of life would that be? And until today, it is still not clear to me what a chance of one out of 280 actually means. 'Chance' wasn't just flowing in my bloodstream, was it? There must have been something in my blood that was not good, but they never explained it to me. Either there was something in my blood or something wasn't in my blood, but there is no 'chance' in it. As lay person I did not get it. Fortunately I went to my midwife and she soothed me. We should have seen something on the echo. Also my mother convinced me that our baby would be just fine and that I should trust my own body and feelings. And you know, there are always risks, you have to accept that. From that moment on, I pushed it away until the birth of Joan. And although I pushed it away successfully, the relief was immense when everything turned out to be right when she was born. I never went back to that doctor again, I was so angry at him, at the situation, at myself, for being so naïve. The doctor never told me what an acceptable chance was, or when it would be wise to do a puncture or not. He simply advised me just to do the test first and then we would see what's next. Now I know that's not wise. You should think about what you would want to do with every possible outcome. People should know whether they want to know it, why they want to know it, and what they would do if they knew it. In the end I chose that I didn't want to know, in good faith and hoping for the best. 
Box 2. Books and articles (for the saturation strategy concerning the ELSA of medical decision-making).

\begin{tabular}{|c|c|c|}
\hline 1. & (Bates, 2003) & 19. (Nyrhinen, Leino-Kilpi, \& Hietala, 2004) \\
\hline 2. & (Beauchamp \& Childress, 2001) & 20. (Nyrhinen, Hietala, Puukka, \& Leino-Kilpi, 2007) \\
\hline 3. & (Bolt, Verweij, \& Van Delden, 2005) & 21. (Pin \& Gutteling, 2005) \\
\hline 4. & (Borkenhagen et al., 2007) & 22. (Resnik, 2003) \\
\hline 5. & (Challen, Harris, Benjamin, \& Harris, 2006) & 23. (Rosner, 2004) \\
\hline 6. & (Cherry \& Cherry, 2003) & 24. (Rowley, 2007) \\
\hline 7. & (Collins, Green, Guttmacher, \& Guyer, 2003) & 25. (Rudnick, 2007) \\
\hline 8. & (De Visser, 2007) & 26. (Stratton \& Rahman, 2008) \\
\hline 9. & (De Wert, 1999) & 27. (Twomey, 2006) \\
\hline & (Decruyenaere, 2003) & 28. (Vähäkangas, 2001) \\
\hline & (Dols-Caanen, Konings, Gómez Garcia, \& Schrander- & 29. (Van Baarsen, 2003) \\
\hline & Stumpel, 2008) & 30. (Van Kleffens, Van Baarsen, \& Van Leeuwen, 2004) \\
\hline & (Finck, Meister, Stöbel-Richter, Borkenhagen, \& Brähler, & 31. (Van Neste, 1993) \\
\hline & 2006) & 32. (Wilfond, 1995) \\
\hline & (Frets, 1990) & 33. (Wüstner \& Heinze, 2007) \\
\hline & (Grient Dreux, Kooijman, \& Korenromp, 2008) & 34. (Yesley, 2008) \\
\hline 15 . & (Grob, 2006) & 35. (Zallen, 1997) \\
\hline \multicolumn{3}{|c|}{ 16. (Guttmacher, Porteous, \& McInerney, 2007) } \\
\hline \multicolumn{3}{|c|}{ 17. (Harvey et al., 2007) } \\
\hline \multicolumn{3}{|c|}{ 18. (Hietala et al., 1995) } \\
\hline
\end{tabular}

